\title{
Evolution of C-Reactive Protein
}

Asmita Pathak and Alok Agrawal ${ }^{*}$

Department of Biomedical Sciences, James H. Quillen College of Medicine, East Tennessee State University, Johnson City, $T N$, United States

C-reactive protein (CRP) is an evolutionarily conserved protein. From arthropods to humans, CRP has been found in every organism where the presence of CRP has been sought. Human CRP is a pentamer made up of five identical subunits which binds to phosphocholine (PCh) in a $\mathrm{Ca}^{2+}$-dependent manner. In various species, we define a protein as CRP if it has any two of the following three characteristics: First, it is a cyclic oligomer of almost identical subunits of molecular weight 20-30 kDa. Second, it binds to PCh in a $\mathrm{Ca}^{2+}$-dependent manner. Third, it exhibits immunological cross-reactivity with human CRP. In the arthropod horseshoe crab, CRP is a constitutively expressed protein, while in humans, CRP is an acute phase plasma protein and a component of the acute phase response. As the nature of CRP gene expression evolved from a constitutively expressed protein in arthropods to an acute phase protein in humans, the definition of CRP became distinctive. In humans, CRP can be distinguished from other homologous proteins such as serum amyloid $\mathrm{P}$, but this is not the case for most other vertebrates and invertebrates. Literature indicates that the binding ability of CRP to PCh is less relevant than its binding to other ligands. Human CRP displays structurebased ligand-binding specificities, but it is not known if that is true for invertebrate CRP. During evolution, changes in the intrachain disulfide and interchain disulfide bonds and changes in the glycosylation status of CRP may be responsible for different structurefunction relationships of CRP in various species. More studies of invertebrate CRP are needed to understand the reasons behind such evolution of CRP. Also, CRP evolved as a component of and along with the development of the immune system. It is important to understand the biology of ancient CRP molecules because the knowledge could be useful for immunodeficient individuals.

Keywords: C-reactive protein, pentraxin, serum amyloid P, phosphocholine, PTX3

\section{INTRODUCTION}

Human C-reactive protein (CRP) was identified as a plasma protein which, in the presence of $\mathrm{Ca}^{2+}$, precipitated C-polysaccharide ( $\mathrm{PnC}$ ) isolated from the cell wall of Streptococcus pneumoniae (1). The precipitation was due to the binding of CRP to phosphocholine (PCh) moiety present in PnC (2). In animals, we define a protein as CRP if it has at least two of the following three characteristics: First, it is a cyclic oligomer of almost identical subunits of molecular weight $20-30 \mathrm{kDa}$. Second, it binds to $\mathrm{PCh}$ in a $\mathrm{Ca}^{2+}$-dependent manner. Third, it exhibits immunological cross-reactivity with human CRP.

CRP is an evolutionarily conserved protein. From arthropods to humans, CRP has been found in every organism where the presence of CRP has been sought (3-8). In the arthropod horseshoe crab, CRP is a constitutively expressed protein found in the hemolymph (8). After $\sim 500$ million 
years of evolution, in humans and some other species, CRP became a protein which is expressed as a component of the acute phase response (9). The aim of this paper was to review the changes observed in the structure and ligandbinding specificities of CRP during evolution. We reviewed the literature on the structure and ligand-binding specificities of CRP from the following animals from arthropods to humans: American horseshoe crab, giant African snail, 17 different species of fish, chicken, frog, cow, dog, guinea pig, horse, hamster, mouse, goat, rat, rabbit, monkey, pig, mink, elephant, squirrel, seal, phascogale, and man. We compared the primary structure of CRP and searched for the conservation of functionally critical amino acid residues that are known for human CRP (Figure 1). We also compared the overall quaternary structure (Table 1), ligand-binding specificities, and immunological cross-reactivity of CRP (Table 2), if known. Two other proteins, serum amyloid P component (SAP), also known as pentraxin-2, and long pentraxin (PTX3), which share several structural and functional properties with CRP, are not reviewed here $(3,56)$.

\section{CRP IN AN ARTHROPOD}

A protein that fits the definition of CRP is present in the hemolymph of the arthropod American horseshoe crab, Limulus polyphemus (5, 6, 10-13, 57-59). Limulus CRP binds to PCh in a $\mathrm{Ca}^{2+}$-dependent manner and precipitates PnC. Limulus CRP exhibits immunological cross-reactivity against snail CRP; the cross-reactivity against human CRP and rabbit CRP is weak. Limulus CRP is made of three types of subunits, each subunit having 218 amino acid residues, encoded by three homologous genes. The three subunits, which share an identical $\mathrm{N}$-terminal sequence of 44 amino acid residues and a C-terminal sequence from amino acid residues 206218 , exist approximately in equimolar amount and are tightly associated. Hexagonal Limulus CRP, as revealed by electron microscopy, consists of two copies of each type of subunit. The positions of six half-cystines that form three intrachain disulfide bonds and the site of glycosylation are constant in all subunits. The molecular weight of Limulus CRP is $\sim 300$ $\mathrm{kDa}$. The molecular weight of the subunits is $\sim 25 \mathrm{kDa}$. Thus, there are 12 subunits in one Limulus CRP molecule, that is, two hexamers stacked together. The concentration of CRP in Limulus hemolymph is $\sim 2.0 \mathrm{mg} / \mathrm{ml}$. It remains to be determined whether Limulus CRP is an acute phase protein. Limulus CRP has also been shown to chelate the heavy metals mercury and cadmium, and hence playing a role in detoxification of heavy metals. Such a detoxification function of Limulus CRP is not known for human CRP. Uniquely, Limulus CRP has also been shown to exhibit $\mathrm{Ca}^{2+}$-independent binding to membranes mimicking the outer membrane of Gram-negative bacteria and then create pores in the lipid bilayer $(5,6,10-13,57-59)$.

Abbreviations: CRP, C-reactive protein; FP, female protein; LDL, low density lipoprotein; PCh, phosphocholine; PnC, pneumococcal C-polysaccharide; SAP, serum amyloid $\mathrm{P}$ component.

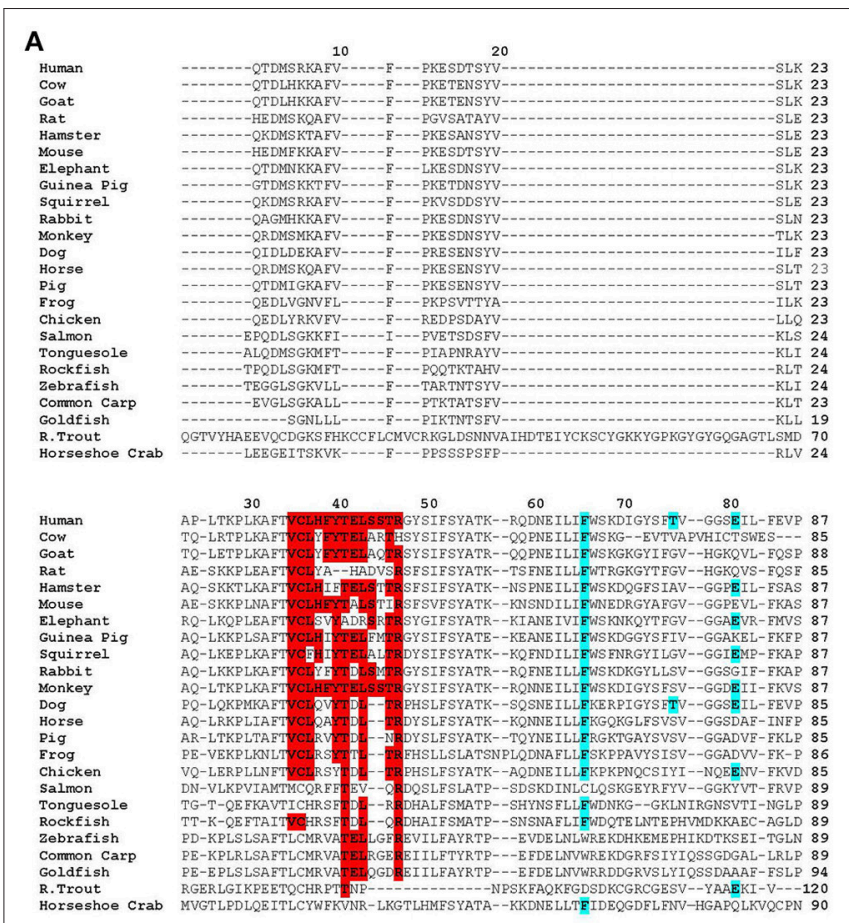

B
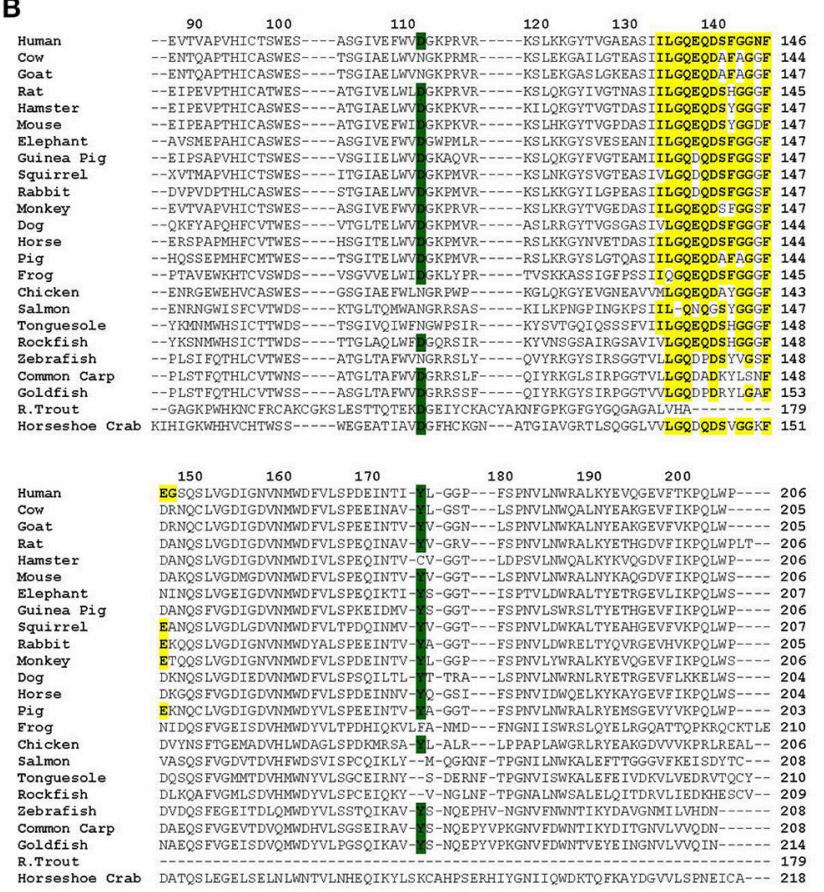

FIGURE 1 | Alignment of the primary structure of CRP from various species using Clustal Omega (1.2.4) EMBL-EBI multiple sequence alignment software. Sequences were obtained from NCBI in FASTA format and copied into the EMBL-EBI alignment software where the output result was obtained in the format of ClustalW with character counts. For horse and horseshoe crab, there were several sequences due to the presence of isoforms. Since the microheterogeneity between these isoforms was $<10 \%$, the first isoform sequence was selected. Accession numbers of the sequences are: Horseshoe crab, AAA28270; Rainbow trout, NP001118197.1; Goldfish, AK022072.1;

(Continued) 
FIGURE 1 | Common carp, AEU04519; Zebrafish, AGB69036; Rockfish, AKR17056; Tonguefish, NP001281151; Salmon, NP001134140; Chicken, ABD16281; Frog, NP001165686; Pig, NP999009; Horse, XP001504452; Dog, CDF47287; Monkey, XP001117250; Rabbit, NP001075734; Squirrel, XP026263752.1; Guinea pig, AAC60662; Elephant, XP006895510.1; Mouse, AFA37877; Hamster, XP005078251; Rat, AFA37869; Goat, XP017901842; Cow, NP001137569; and Human, AAL48218. The sequence of the signal peptide is not shown. The column on the right shows the number of amino acid residues in each CRP. (A) Sequence of amino acid residues 1-87 of human CRP aligned with the sequence of CRP from other animals. Conserved amino acid residues in the following functional sites are highlighted: The intrinsically disordered region in CRP (amino acid residues 35-46 in human CRP) is highlighted in red. The PCh-binding site (amino acid residues 66, 76, and 81 in human CRP) is highlighted in blue. (B) Sequence of amino acid residues 88-206 of human CRP aligned with the sequence of CRP from other animals. Conserved amino acid residues in the following functional sites are highlighted: The C1q-binding site (amino acid residues 112 and 175 in human CRP) is highlighted in green. The $\mathrm{Ca}^{2+}$-binding site (amino acid residues 134-148 in human CRP) is highlighted in yellow.

\section{CRP IN A MOLLUSC}

Based on the reactivity with anti-Limulus CRP antibodies, CRP was detected in the hemolymph of the mollusc, giant African snail, Achatina fulica $(14,15,60-62)$. Achatina CRP binds to PCh in a $\mathrm{Ca}^{2+}$-dependent manner. The molecular weight of Achatina $\mathrm{CRP}$ is $\sim 400 \mathrm{kDa}$. Achatina $\mathrm{CRP}$ is glycosylated and has two types of subunits, of molecular weight 20 and $24 \mathrm{kDa}$. Although antiLimulus CRP antibodies react with Achatina CRP, anti-Achatina CRP antibodies do not react with Limulus CRP. Achatina CRP is a constitutively expressed protein and one of the major components of the haemolymph with a normal level of $\sim 2.0$ $\mathrm{mg} / \mathrm{ml}$. Like Limulus CRP, Achatina CRP has also been shown to bind to heavy metals and it has been proposed that Achatina CRP may be utilized as a viable exogenous agent of cytoprotection against heavy metal-related toxicity. In addition, Achatina CRP has been found to be bacteriostatic against gram negative bacteria and bactericidal against gram positive bacteria $(14,15,60-62)$.

\section{CRP IN FISH}

CRP was first found in the serum of a marine teleost fish, plaice, Pleuronectes platessa (16-19) and has been isolated and characterized mostly from teleost fish. Plaice CRP binds to $\mathrm{PCh}$ in a $\mathrm{Ca}^{2+}$-dependent manner and looks pentameric in its electron microscopic appearance. The molecular weight of plaice CRP is $\sim 187 \mathrm{kDa}$, consisting of 10 non-covalently associated subunits arranged in two pentameric discs. There are two distinct subunits in plaice CRP; the difference in size between the subunits is due to carbohydrates since the heavier subunit is glycosylated while the lighter one is not. Plaice CRP is present at a concentration of $55 \mu \mathrm{g} / \mathrm{ml}$ and is not an acute phase protein because its serum concentration does not increase in response to turpentine. However, adrenal hormones and endotoxins do cause an increase in circulating CRP in plaice (16-19). A CRP-like protein has also been purified from the eggs of another marine teleost, lumpsucker, Cyclopterus lumpus $(20,21)$. The molecular weight of lumpsucker CRP is in the range of 125 and $150 \mathrm{kDa}$. Lumpsucker CRP consists of identical, non-covalently bound subunits of molecular weight $20-21.5 \mathrm{kDa}$.

CRP is also present in the sera of another teleost, the rainbow trout species, Salmo gairdneri and Oncorhynchus mykiss (22, 6367). Trout CRP binds to $\mathrm{PCh}$ in a $\mathrm{Ca}^{2+}$-dependent manner, precipitates $\mathrm{PnC}$, is a glycoprotein, and has 179 amino acid residues. According to one study, the molecular weight of rainbow trout CRP is $110 \mathrm{kDa}$, while that of the subunits is $\sim 20 \mathrm{kDa}$. According to another study, the molecular weight of rainbow trout CRP is $81.4 \mathrm{kDa}$, it is a trimer, and composed of one monomer subunit $(26.6 \mathrm{kDa})$ and one disulfide-linked dimer $(43.7 \mathrm{kDa})$. However, there exists the possibility that a hexamer or a double-stacked hexamer was separated into two or four trimers. The CRP level in normal trout sera is in the range of $30-88 \mu \mathrm{g} / \mathrm{ml}$. Trout CRP is an acute phase protein because its concentration increases in response to toxic chemicals and bacterial pathogens (22, 63-67). Cod, Gadus morhua, CRP that exhibits $\mathrm{Ca}^{2+}$-dependent binding to $\mathrm{PCh}$, is glycosylated, and is a pentamer in its electron microscopic appearance. The size of the subunits in cod CRP varies in the range of $22-29 \mathrm{kDa}(23,24)$.

Among other teleosts, CRP has been isolated from the sera of eels Anguilla anguilla and Anguilla japonica $(25,26)$. Eel CRP binds to PCh in a $\mathrm{Ca}^{2+}$-dependent manner and agglutinates $S$. pneumoniae. The molecular weight of eel CRP is $120 \mathrm{kDa}$ and the subunits are non-glycosylated, with a molecular weight of 24 $\mathrm{kDa}$. The serum levels of eel CRP is $\sim 1 \mu \mathrm{g} / \mathrm{ml}$. CRP is present in channel catfish Ictalurus punctatus (27). Catfish CRP binds to $\mathrm{PCh}$ and precipitates $\mathrm{PnC}$ in a $\mathrm{Ca}^{2+}$-dependent manner. Catfish CRP is a non-glycosylated protein with a molecular weight of $\sim 100 \mathrm{kDa}$. Electron microscopy has shown that catfish CRP has a planar pentagonal symmetry. The serum titer of catfish CRP follows an acute phase pattern in catfish injected with turpentine. Striped catfish, Pangasianodon hypophthalmus, CRP binds to $\mathrm{PCh}$ in a $\mathrm{Ca}^{2+}$-dependent manner, is a trimer of $28 \mathrm{kDa}$ subunits, can exist as tetramers of trimers, is devoid of interchain disulfide bonds, is glycosylated, and agglutinates a few species of pathogenic bacteria (28). A CRP gene in ayu, Plecoglossus altivelis, has been identified (29). The expression of ayu CRP is upregulated following bacterial infection. Ayu CRP agglutinates both gram negative and positive bacteria in a $\mathrm{Ca}^{2+}$-dependent manner. Ayu CRP is not glycosylated, has a molecular weight of $25.2 \mathrm{kDa}$, and has 225 amino acid residues.

In cyprinids, the carp family fish rohu, Labeo rohita, CRP has been purified by their $\mathrm{Ca}^{2+}$-dependent binding to PCh $(30,68$, 69). There are three types of glycosylated subunits in rohu CRP, and all three types of subunits move to identical position after desialylation and deglycosylation. Rohu CRP appears pentameric under electron microscope and is composed of identical subunits of molecular weight $33 \mathrm{kDa}$. Rohu CRP is an acute phase protein because its concentration in serum increases in response to heavy metal poisoning of water. In common carp Cyprinus carpio, CRP CRP displays $\mathrm{Ca}^{2+}$-dependent binding to phosphate monoesters (31, 37, 70-72). Common carp CRP is glycosylated, has 208 amino acid residues, and the molecular weight of the subunits is $27 \mathrm{kDa}$. A potential commercial use of CRP, which is constitutively expressed in common carp, is as a biomarker of 
TABLE 1 | Properties of CRP isolated from various animals. See the text for scientific names of the animals.

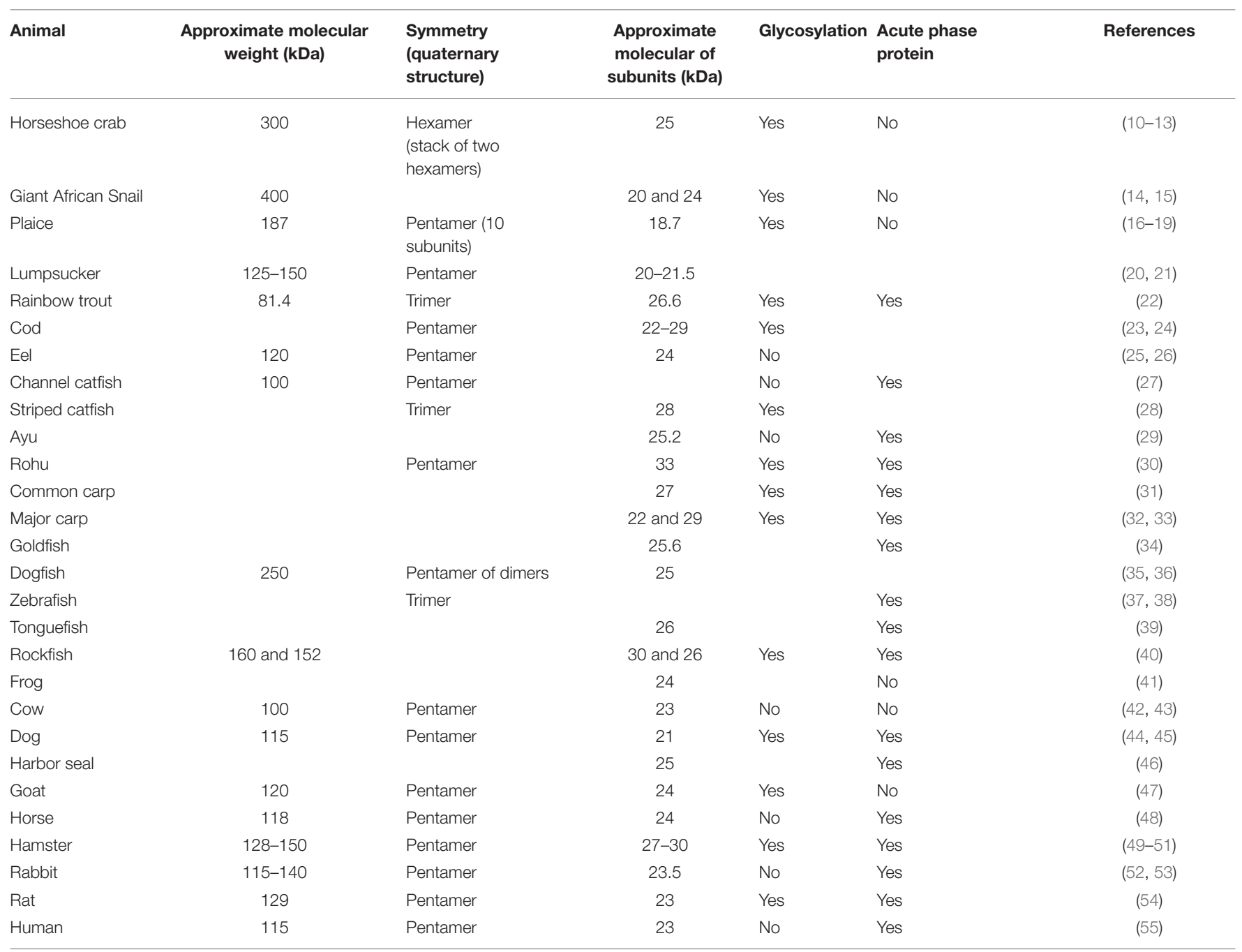

health status in cultured carp. Serum level of CRP in common carp infected with some but not all pathogens increases severalfold, suggesting that common carp CRP is a minor acute phase protein. CRP has also been purified from the sera of major carp Catla catla $(32,33)$. Kinetic studies of metal intoxication in major carp indicated that a unique molecular variant of CRP is present in the serum at the peak level of acute phase induction, and this variant coexists with normal CRP. Major carp CRP is a glycoprotein, contains two non-identical subunits of molecular weight 22 and $29 \mathrm{kDa}$, and binds to $\mathrm{PCh}$ in a $\mathrm{Ca}^{2+}$. dependent manner. The electrophoretic mobility of the subunits is identical after desialylation and deglycosylation implying that the molecular variants vary in the glycan parts. The expression of CRP during the course of parasitic infection in the goldfish, Carassius auratus, was also determined (34); goldfish CRP, which has 214 amino acid residues and has subunits of $25.6 \mathrm{kDa}$, enhances complement-mediated killing of trypanosomes in vitro, and lysis increases after addition of immune serum.

Dogfish, Mustelus canis, CRP also binds to $\mathrm{PCh}$ in a $\mathrm{Ca}^{2+}$. dependent manner and precipitates PnC $(35,36,73)$. Dogfish
CRP has a molecular weight of $\sim 250 \mathrm{kDa}$ with subunits of molecular weight of $\sim 25 \mathrm{kDa}$. Dogfish CRP probably exists as pentamers of two disulfide-linked dimers; however, the crystals of the protein were found to contain two hexamers in the asymmetric unit. Dogfish CRP is present at a concentration of $400 \mu \mathrm{g} / \mathrm{ml}$. Dogfish CRP exhibits immunological cross-reactivity with rabbit CRP. The CRP gene from zebrafish, Danio rerio, a bony fish, has been cloned, expressed, protein purified, and crystallized $(37,38,74,75)$. There are seven CRP-like genes in zebrafish which are differentially expressed both normally and in acute phase and have anti-viral activities. Zebrafish CRP is trimeric, and each subunit has 208 amino acid residues. In tonguefish, a flat fish, CRP is composed of 210 amino acid residues with a subunit molecular weight of $\sim 26 \mathrm{kDa}$ (39). Expression of tonguefish CRP is upregulated by pathogen infection. Tonguefish CRP has been found to interact with both gram positive and negative bacteria.

In rockfish, Sebastes taczanowskii, CRP is a sex-limited protein (40). CRP is induced in the serum of males by estrogen administration. Serum levels in females during vitellogenic and 
TABLE 2 | Immunological cross-reactivity among CRP from various animals.

\begin{tabular}{|c|c|c|c|c|c|c|c|}
\hline \multirow[t]{2}{*}{ Reactivity with serum or CRP } & \multicolumn{7}{|c|}{ Anti-CRP antibodies or antiserum } \\
\hline & Human & Sheep & Rabbit & Dog & Cow & Goat & Horseshoe crab \\
\hline Human & $\sqrt{ }$ & & & & $\sqrt{ }$ & $\sqrt{ }$ & $\sqrt{ }$ \\
\hline Sheep & & $\sqrt{ }$ & & & & $\sqrt{ }$ & \\
\hline Rabbit & $\sqrt{ }$ & & $\sqrt{ }$ & & & & $\sqrt{ }$ \\
\hline Dog & $\sqrt{ }$ & & & $\sqrt{ }$ & & & \\
\hline Cow & $\sqrt{ }$ & & & & $\sqrt{ }$ & $\sqrt{ }$ & \\
\hline Goat & $\sqrt{ }$ & & & & $\sqrt{ }$ & $\sqrt{ }$ & \\
\hline \multicolumn{8}{|l|}{ Rat } \\
\hline Mouse & & $\sqrt{ }$ & & & & & \\
\hline Elephant & & & & $\sqrt{ }$ & & & \\
\hline Horse & $\sqrt{ }$ & & & & & & \\
\hline Monkey & $\sqrt{ }$ & $\sqrt{ }$ & & & & & \\
\hline Cat & $\sqrt{ }$ & & & & & & \\
\hline Sheep & $\sqrt{ }$ & & & & $\sqrt{ }$ & & \\
\hline Dogfish & & & $\sqrt{ }$ & & & & \\
\hline Snail & & & & & & & $\sqrt{ }$ \\
\hline Horseshoe crab & $\sqrt{ }$ & & $\sqrt{ }$ & & & & $\sqrt{ }$ \\
\hline
\end{tabular}

Only those animals are shown for which at least one immunological cross-reactivity is known. See the text for references.

gestation periods are about 1,000 times higher than those in the normal males. In the presence of $\mathrm{Ca}^{2+}$, rockfish CRP binds to PCh and agglutinates S. pneumoniae. In rockfish, two types of CRP are found, with molecular weights 160 and $152 \mathrm{kDa}$, with subunits of 30 and $26 \mathrm{kDa}$, respectively. Both subunits are glycosylated. In another species of rockfish, Sebastes schlegelii, CRP contains 208 amino acid residues with a molecular weight of $25 \mathrm{kDa}$ (76). In Atlantic salmon Salmo salar, five CRP-like molecules are present (77). Salmon CRP has 208 amino acid residues, is not an acute phase protein, and only one of five CRP species is upregulated by cytokines.

\section{CRP IN BIRDS, REPTILES, AND AMPHIBIANS}

So far, the presence of CRP has been investigated only in the fowl Gallus gallus. In chickens, CRP has 206 amino acid residues. The mRNA for CRP was found in many tissues from the fowl by using a probe derived from human CRP cDNA $(78,79)$. Although genes are present in lizards, the CRP protein has not been isolated and characterized from any reptile (77). Among amphibians, CRP has been isolated from the frog Xenopus laevis (41). Frog CRP has 210 amino acid residues. Xenopus CRP is present at an intermediate low level of $\sim 1 \mu \mathrm{g} / \mathrm{ml}$ in the normal serum. Frog CRP level in the serum is not induced by turpentine. It is suggested that frog CRP represents a transitional period in the evolution of CRP, when host defenses switched from primitive innate immunity to the immune system. The constitutive functions of CRP gradually became less essential as a result of the development of a complex immune system (41).

\section{CRP IN MAMMALS}

CRP from cow, Bos taurus, has been purified from the serum $(42,43,80)$. Unlike human CRP, bovine CRP does not precipitate PnC. However, bovine CRP exhibits immunological crossreactivity with human, goat and sheep CRP. Bovine CRP is a pentameric molecule with a molecular weight of $\sim 100 \mathrm{kDa}$ and is composed of five identical non-glycosylated subunits of molecular weight of $\sim 23 \mathrm{kDa}$. Each subunit has one intrachain disulfide bond. The pentameric structure of bovine CRP was seen by electron microscopy. The concentration of bovine CRP is in the range of $5-40 \mu \mathrm{g} / \mathrm{ml}$ and it is not an acute phase protein $(42,43,80)$.

CRP from dogs, Canis lupus, exhibits $\mathrm{Ca}^{2+}$-dependent binding to PCh $(44,45,81-88)$. Dog CRP has the typical cyclic pentameric disc-like structure in its electron microscopic appearance, although the pentamer stacks. Dog CRP has 204 amino acid residues and a molecular weight of $\sim 100 \mathrm{kDa}$. Dog CRP is composed of five subunits of $\sim 20 \mathrm{kDa}$ with an intrachain disulfide bond in each subunit. In another study, the molecular weight of dog CRP was estimated to be $\sim 156 \mathrm{kDa}$. In one study, two isotypes of CRP with different molecular weights, 22 and 25 $\mathrm{kDa}$ were found, with the $25 \mathrm{kDa}$ subunit glycosylated. Two of the five subunits in the pentamer were glycosylated. Antibodies to human CRP react with dog CRP, but antibodies to dog CRP do not react with human CRP. However, antibodies to dog CRP was used to detect CRP in elephants. CRP Normal healthy dogs contain $\sim 5-60 \mu \mathrm{g} / \mathrm{ml}$ of CRP but, following a stimulus, CRP behaves as an acute phase protein $(44,45,81-88)$.

Guinea pig CRP has 206 amino acid residues and has not been characterized fully, but the gene has organization typical of the CRP genes of other mammals. Guinea pig CRP is not an acute phase protein (89). Harbor seal, Phoca vitulina, CRP 
binds to $\mathrm{PCh}$ in a $\mathrm{Ca}^{2+}$-dependent manner and has a molecular weight of $\sim 25 \mathrm{kDa}$ (46). A CRP-like protein has also been isolated from goat serum (47). Direct binding of goat CRP to PCh has not been shown; however, fluid phase PCh inhibits the $\mathrm{Ca}^{2+}$-dependent binding of goat CRP to its ligand agarose. Goat CRP is composed of five identical, glycosylated, non-covalently associated subunits, each of molecular weight $\sim 24 \mathrm{kDa}$. Goat CRP possesses immunological cross-reactivity with human, cow and sheep CRP. Like in cows and guinea pigs, CRP in goats is not an acute phase protein (47). CRP in horses has pentameric structure as revealed by electron microscopy and binds to PCh in a $\mathrm{Ca}^{2+}$-dependent manner $(48,90)$. Horse CRP has 204 amino acid residues and a molecular weight of $\sim 118 \mathrm{kDa}$. Horse CRP is composed of five identical, non-glycosylated and noncovalently associated subunits with molecular weight of $\sim 23$ $\mathrm{kDa}$. Equine CRP displays immunochemical cross-reactivity with human CRP. In horses, CRP is an acute phase protein $(48,90)$. Monkey CRP has 206 amino acid residues and precipitates PnC; however, monkey CRP was first isolated by $\mathrm{Ca}^{2+}$-dependent binding to organic monophosphates. Monkey CRP reacts with anti-sheep CRP antibodies but not with anti-dog CRP antibodies (91). CRP from pigs has 203 amino acid residues but not been characterized fully yet. Porcine CRP is an acute phase protein $(92,93)$.

A CRP-like protein named female protein (FP) was found in Syrian and Armenian hamsters $(49-51,94-96)$. FP is a prominent serum constituent of normal female hamsters but is under hormonal control in males. However, in normal adult male hamsters, FP in serum increases only about 5 -fold during an acute phase response, in contrast to human CRP which may increase 1,000-fold or more. FP has a pentameric structure as indicated by electron microscopy and binds to $\mathrm{PCh}$ in a $\mathrm{Ca}^{2+}$. dependent manner. FP has 206 amino acid residues with a molecular weight in the range of $128-150 \mathrm{kDa}$. The molecular weight of each of the five non-covalantly assembled glycosylated subunits is in the range of $26-30 \mathrm{kDa}$; each subunit contains a single intrachain disulphide bond. In the presence of $\mathrm{Ca}^{2+}$, FP aggregates, probably to form decamers (49-51, 94-96). In mice (97-100), CRP is not an acute phase protein. Murine CRP agglutinates several strains of gram-positive bacteria in vitro. Murine CRP has 206 amino acid residues. Protein modeling has demonstrated that adaptively selected amino acid residues in murine CRP lie in the ligand-binding region and contact region between subunits (97-100).

Rabbit CRP reacts with PCh and precipitates PnC in a $\mathrm{Ca}^{2+}$-dependent manner $(52,53,91,101-120)$. CRP was found localized at sites of inflammation in rabbits and was not observed at the inflammatory site before appearance in the blood. The concentration of rabbit CRP in the serum is $\sim 1.5 \mu \mathrm{g} / \mathrm{ml}$. Investigation of rabbit CRP provided evidence that CRP molecules expressing a structure and antigenicity that are distinct from native CRP occurs in vivo, and that such molecules accumulate at sites of inflammation. Rabbit CRP has 205 amino acid residues and is pentameric. The molecular weight of rabbit CRP lies between $115-140 \mathrm{kDa}$. The subunit size is $23.5 \mathrm{kDa}$. For precipitation of the PCh-ligands, only the binding of the phosphoryl group of PCh to rabbit CRP is required, unlike for human CRP where binding to both the phosphoryl and cationic groups of $\mathrm{PCh}$ are needed for precipitation. Transgenic mice expressing rabbit CRP are partially protected from a lethal challenge of endotoxin or platelet activating factor. Rabbit CRP is capable of activating complement when bound to a ligand; however, complement activation is not required to mediate protection against either endotoxins or platelet activating factor. Immobilized rabbit CRP binds to low-density lipoprotein (LDL) also. In rabbits, CRP has been found associated with the progression of atherosclerosis $(52,53,101-120)$.

Rat CRP is unique when compared to CRP from other mammalian species $(54,111,112,121-133)$. Rat CRP has five subunits arranged as a cyclic pentamer and is the only mammalian CRP which is glycosylated and contains a covalently linked dimer in its pentameric structure. Rat CRP binds to PCh in a $\mathrm{Ca}^{2+}$-dependent manner but does not precipitate PnC. The non-glycosylated rat CRP is also able to bind to PCh. Rat CRP is made up of 206 amino acid residues. One pair of the subunits per molecule is linked by two interchain disulphide bonds, that is, the five subunits are not non-covalently associated. The other three subunits have intrachain disulfide bonds. Rat CRP is present at a concentration of $0.3-0.5 \mathrm{mg} / \mathrm{ml}$ and is not an acute phase protein. Immobilized rat CRP is capable of binding to LDL also in a $\mathrm{Ca}^{2+}$. dependent and PCh-inhibitable manner; however, the binding ability of rat CRP to PCh is not a sufficient requirement for the interaction between rat CRP and LDL. A sialic acid moiety must also be present on rat CRP for binding to LDL. LDL is modified once it is complexed with rat CRP. Like Limulus CRP, rat CRP has also been shown to play a role in detoxification of heavy metals such as mercury $(54,111,112,121-133)$.

Mink presents an unusual case (134): it is called mink SAP. However, mink SAP is not glycosylated unlike SAP in other mammals. Mink SAP binds to PCh also, unlike SAP in other mammals. The molecular weight of mink SAP subunits is $\sim 26$ $\mathrm{kDa}$. The presence of mRNA for CRP has also been found by using a probe derived from human CRP cDNA in many tissues from Asian elephant Elephas maximus $(135,136)$ and ground squirrel Spermophilus richarsonii (137). CRP is also present in elephant seal Mirounga angustirostris (138). A gene sequence for CRP is also found in marsupial genome, red-tailed phascogale Phascogale calura (139).

\section{HUMAN CRP}

In humans, CRP is a major acute phase protein whose concentration may increase more than 1,000-fold in severe inflammatory states (9). Human CRP is a pentameric protein composed of five identical non-covalently bound subunits of 206 amino acid residues with a molecular weight of $\sim 23 \mathrm{kDa}$. Human CRP binds to $\mathrm{PCh}$ in a $\mathrm{Ca}^{2+}$-dependent manner. There are five PCh-binding sites, one located on each subunit. Each subunit binds two $\mathrm{Ca}^{2+}$ ions $(55,140)$. In human CRP, $\mathrm{Glu}^{81}$ in the PCh-binding site interacts with the nitrogen atom of choline in PCh, Phe ${ }^{66}$ interacts with three methyl groups of choline, and $\mathrm{Thr}^{76}$ is critical for creating the appropriately sized pocket to accommodate PCh. The phosphate group of PCh directly coordinates with the two $\mathrm{Ca}^{2+}$ bound to CRP. Using synthetic peptides derived from CRP, direct binding of $\mathrm{Ca}^{2+}$ to a peptide of residues 134-148 has been shown. Crystallography of CRP 
has demonstrated that two $\mathrm{Ca}^{2+}$ ions are co-ordinated by $\mathrm{Asp}^{60}$, $\mathrm{Asn}^{61}$, and by residues $\mathrm{Glu}^{138}, \mathrm{Gln}^{139}, \mathrm{Asp}^{140}$, Glu ${ }^{147}$, and $\mathrm{Gln}^{150}$ in a loop $(55,141-144)$. Once CRP is bound to a PCh-containing ligand, it activates the classical complement pathway. Residues Asp $^{112}$ and $\mathrm{Tyr}^{175}$ play critical roles in the formation of the C1q-binding site in CRP (145-147).

Acidic $\mathrm{pH}$ transforms native pentameric CRP into another pentameric configuration, called as non-native CRP, which exposes a hidden ligand-binding site for non-PCh ligands, and which enables CRP to bind to immobilized, denatured and aggregated proteins. For example, CRP does not bind to oxidized LDL (ox-LDL) at physiological pH but gains the ability to bind to ox-LDL at acidic $\mathrm{pH}$ (148). $\mathrm{H}_{2} \mathrm{O}_{2}$-treated CRP also gains a ligand recognition property not exhibited by native $\mathrm{CRP}$, indicating that $\mathrm{H}_{2} \mathrm{O}_{2}$, like acidic $\mathrm{pH}$, is another modifier of the structure and ligand recognition function of CRP (149). Immobilization of CRP or mutagenesis of $\mathrm{Glu}^{42}$ in the inter-subunit contact region in pentameric CRP also convert CRP into molecules that bind to a variety of immobilized, denatured and aggregated proteins (148151). A possible binding site in non-native CRP for immobilized, denatured and aggregated proteins could be formed involving the single intrinsically disordered region present in CRP (152). It has been shown that when CRP dissociates into its monomers, monomeric CRP recognizes such protein ligands through the intrinsically disordered region (152).

CRP is a multifunctional component of the human innate host defense machinery. In mouse models of pneumococcal infection, transgenic or passively administered human CRP has been shown to be protective against lethal infection with S. pneumoniae (153160). Similarly, CRP may be an atheroprotective molecule, as shown by using transgenic CRP in animal models of human like atherosclerosis (161-166). CRP has been found deposited at sites of inflammation, indicating the presence of non-native CRP in vivo. The functions of CRP at sites of inflammation have not been defined yet; however, it has been suggested that a structural change in CRP and the resulting shift from the ligand recognition function of CRP in its native conformation to another ligand recognition function in its non-native conformation occurs at sites of inflammation $(151,152,167)$.

Interestingly, human CRP also possesses sites for glycosylation, although the sites are hidden in native CRP (168170). When CRP was isolated from patients with six different pathological conditions, CRP was found to be differentially glycosylated. A few amino acids at the $\mathrm{N}$-terminus and a few amino acids near the C-terminus are missing in glycosylated human CRP. The cleavage of these peptides from CRP exposes two potential sites of glycosylation and these sites are located on CRP on the face opposite to the PCh-binding face of CRP. It has been proposed that glycosylated CRP has a protective role toward the clearance of damaged erythrocytes in diseases.

\section{EVOLUTION OF CRP}

As the nature of CRP gene expression evolved from a constitutively expressed protein in arthropods to an acute phase protein in humans, the definition of CRP also became distinctive. In humans, CRP can easily be distinguished from other homologous proteins such as SAP, but this is not the case in invertebrates. For invertebrates, it has always been difficult to define a protein as either CRP or SAP because of the similarities in their structures and functions. Also, whereas a single CRP gene is present in the human, multiple genes are present in some species, such as Limulus.

There is sequence similarity and homology among the known functional sites of CRP from all species (Figure 1). The PCh-binding property of CRP has been conserved. However, employing animal models of pneumococcal infection it has been shown that the PCh-binding property of human CRP is not the only relevant ligand recognition function of human CRP. Apparently, another ligand-binding property of CRP, such as recognition of complement regulator protein factor $\mathrm{H}$ by CRP in its non-native conformation, is responsible for its host defense functions (160). Because some ancient CRP molecules including bovine CRP do not bind PCh, it has been proposed that the recognition of PCh by CRP is less relevant to the role of the protein than its interaction with other ligands $(42,151,160)$.

Human CRP in its non-native structural conformation expresses the capability to bind to deposited and conformationally altered proteins and which can be achieved by several means including treatment of CRP with acidic $\mathrm{pH}$ (151). The ligand-binding property of human CRP in its nonnative structure has implications for toxic and inflammatory conditions and favors the conservation of CRP throughout evolution. It seems that the host-defense functions of CRP evolved to expose a ligand-binding site only when needed, that is, an inflammatory microenvironment would have to be sensed by CRP first and that CRP would change its structure to execute a function. It is not known, however, whether CRP from invertebrates also exhibits structure-based ligand-binding properties. A recent study has shown that Limulus CRP is capable of binding to immobilized ox-LDL without being pre-treated with acidic $\mathrm{pH}$ (171). During evolution, changes in the intrachain disulfide and interchain disulfide bonds and the changes in the glycosylation status of CRP may also be responsible for the structure-function relationships of CRP in various species.

\section{CONCLUSIONS}

CRP evolved as a component of and along with the development of the entire immune system. Both structure and function of CRP have evolved; however, more studies on CRP from all invertebrates and vertebrates are needed to understand fully the reasons behind the evolution of CRP. Structure-function relationships of CRP from most animals are unknown. We know that the ligand-binding properties of Limulus CRP are not identical to that of native human CRP but overlap the ligand-binding properties of non-native pentameric human CRP that can be generated at inflammatory microenvironments (143, 158). Since the ligand recognition functions of CRP lead to effector functions, it is important to understand the biology of ancient CRP molecules because the knowledge could be useful for immunodeficient individuals: all humans have CRP, but it is not known whether human CRP is functional in all humans. 


\section{AUTHOR CONTRIBUTIONS}

All authors listed have made a substantial, direct and intellectual contribution to the work, and approved it for publication.

\section{REFERENCES}

1. Tillett WS, Francis T Jr. Serological reactions in pneumonia with a nonprotein somatic fraction of pneumococcus. J Exp Med. (1930) 52:561-71.

2. Volanakis JE, Kaplan MH. Specificity of C-reactive protein for choline phosphate residues of pneumococcal C-polysaccharide. Proc Soc Exp Biol Med. (1971) 136:612-4.

3. Pepys MB, Dash AC, Fletcher TC, Richardson N, Munn EA, Feinstein A. Analogues in other mammals and in fish of human plasma proteins, C-reactive protein and amyloid P component. Nature. (1978) 273:168-70.

4. Baltz ML, De Beer FC, Feinstein A, Munn EA, Milstein CP, Fletcher TC, et al. Phylogenetic aspects of C-reactive protein and related proteins. Ann NY Acad Sci USA. (1982) 389:49-75.

5. Maudsley S, Pepys MB. Immunochemical cross-reactions between pentraxins of different species. Immunology. (1987) 62:17-22.

6. Ying S-C, Marchalonis JJ, Gewurz AT, Siegel JN, Jiang H, Gewurz BE, et al. Reactivity of anti-human C-reactive protein (CRP) and serum amyloid $\mathrm{P}$ component (SAP) monoclonal antibodies with limulin and pentraxins of other species. Immunology. (1992) 76:324-30.

7. Nunomura W. C-reactive protein (CRP) in animals: its chemical properties and biological functions. Zool Sci. (1992) 9:499-513.

8. Armstrong PB. Comparative biology of the pentraxin protein family: evolutionarily conserved component of innate immune system. Int Rev Cell Mol Biol. (2015) 316:1-47. doi: 10.1016/bs.ircmb.2015.01.002

9. Kushner I. The phenomenon of the acute phase response. Ann NY Acad Sci USA. (1982) 389:39-48.

10. Robey FA, Liu T-Y. Limulin: a C-reactive protein from Limulus polyphemus. J Biol Chem. (1981) 256:969-75.

11. Nguyen NY, Suzuki A, Cheng S-M, Zon G, Liu T-Y. Isolation and characterization of Limulus C-reactive protein genes. J Biol Chem. (1986) 261:10450-5.

12. Nguyen NY, Suzuki A, Boykins RA, Liu TY. The amino acid sequence of Limulus C-reactive protein: evidence of polymorphism. J Biol Chem. (1986) 261:10456-65.

13. Tennent GA, Bulter PJG, Hutton T, Woolfitt AR, Harvey DJ, Rademacher TW, et al. Molecular characterization of Limulus polyphemus C-reactive protein. I. Subunit composition. Eur J Biochem. (1993) 214:91-7.

14. Mandal C, Biswas M, Nagpurkar A, Mookerjea S. Isolation of a phosphoryl choline-binding protein from the hemolymph of the snail, Achatina fulica. Dev Comp Immunol. (1991) 15:227-39.

15. Mukherjee S, Chatterjee S, Sarkar S, Agarwal S, Kundu R, Maitra S, et al. Mollusc C-reactive protein crosses species barrier and reverses hepatotoxicity of lead in rodent models. Indian J Exp Biol. (2013) 51:623-34.

16. Pepys MB, De Beer FC, Milstein CP, March JF, Feinstein A, Butress N, et al. Creactive protein and serum amyloid $\mathrm{P}$ component in the plaice (Pleuronectes platessa L.), a marine teleost, are homologous with their human counterparts. Biochim Biophys Acta. (1982) 704:123-33.

17. White A, Fletcher TC, Pepys MB, Baldo BA. The effect of inflammatory agents on C-reactive protein and serum amyloid P-component levels in plaice (Pleuronectes platessa L.) serum. Comp Biochem Physiol. (1981) 69:325-9.

18. White A, Fletcher TC. The effects of adrenal hormones, endotoxin and turpentine on serum components of the plaice (Pleuronectes platessa L.). Comp Biochem Physiol. (1982) 73:195-200.

19. White A, Fletcher TC. The influence of hormones and inflammatory agents on C-reactive protein, cortisol and alanine aminotransferase in the plaice (Pleuronectes platessa L). Comp Biochem Physiol. (1985) 80C:99-104.

20. White A, Fletcher TC, Towler CM, Baldo BA. Isolation of a C-reactive protein-like precipitin from the eggs of the lumpsucker (Cyclopterus lumpus L.). Comp Biochem Physiol. (1978) 61C:331-6.

\section{ACKNOWLEDGMENTS}

We are grateful to Irving Kushner, M.D., for reviewing the manuscript and for his helpful suggestions.

21. Fletcher TC, White A, Youngson A, Pusztai A, Baldo BA. Characterization of C-reactive protein from the eggs of the marine teleost Cyclopterus lumpus L. Biochim Biophys Acta. (1981) 671:44-9.

22. Murai T, Kodama $H$, Naiki M, Mikami $T$, Izawa $H$. Isolation and characterization of rainbow trout C-reactive protein. Dev Comp Immunol. (1990) 14:49-58.

23. Lund V, Olafsen JA. A comparative study of pentraxin-like proteins in different fish species. Dev Comp Immunol. (1998) 22:185-94.

24. Gisladottir B, Gudmundsdottir S, Brown L, Jonsson ZO, Magnadottir B. Isolation of two C-reactive protein homologues from cod (Gadus morhua L.) serum. Fish Shellfish Immunol. (2009) 26:210-9. doi: 10.1016/j.fsi.2008.03.015

25. Uhlenbruck G, Janssen E, Javeri S. Two different anti-galactan lectins in eel serum. Immunobiology. (1982) 163:36-47.

26. Nunomura W. C-reactive protein in eel: purification and agglutinating activity. Biochim Biophys Acta. (1991) 1076:191-6.

27. Szalai AJ, Norcum MT, Bly JE, Clem LW. Isolation of an acutephase phosphorylcholine-reactive pentraxin from channel catfish (Ictalurus punctatus). Comp Biochem Physiol. (1992) 102B:535-43.

28. Huong Giang DT, Driessche EV, Vandenberghe I, Devreese B, Beeckmans $\mathrm{S}$. Isolation and characterization of SAP and CRP, two pentraxins from Pangasianodon (Pangasius) hypophthalmus. Fish Shellfish Immunol. (2010) 28:743-53. doi: 10.1016/j.fsi.2010.01.007

29. Shi Y-H, Chen K, Ma WJ, Chen J. Ayu C-reactive protein/serum amyloid $\mathrm{P}$ agglutinates bacteria and inhibits complementmediated opsonophagocytosis by monocytes/macrophages. Fish Shellfish Immunol. (2018) 76:58-67. doi: 10.1016/j.fsi.2018. 02.038

30. Sinha S, Mandal C. Microheterogeneity of C-reactive protein in the sera of fish Labeo rohita induced by metal pollutants. Biochem Biophys Res Comm. (1996) 226:681-7.

31. Cartwright JR, Tharia HA, Burns I, Shrive AK, Hoole D, Greenhough TJ. Isolation and characterisation of pentraxin-like serum proteins from the common carp Cyprinus carpio. Dev Comp Immunol. (2004) 28:113-25. doi: 10.1016/S0145-305X(03)00123-X .

32. Paul I, Mandal C, Mandal C. Effect of environmental pollutants on the Creactive protein of a freshwater major carp, Catla catla. Dev Comp Immunol. (1998) 22:519-32.

33. Paul I, Mandal C, Allen AK, Mandal C. Glycosylated molecular variants of C-reactive proteins from the major carp Catla catla in fresh and polluted aquatic environments. Glycoconj J. (2001) 18:54756. doi: 10.1023/A:1019696430477

34. Kovacevic N, Hagen MO, Xie J, Belosevic M. The analysis of the acute phase response during the course of Trypanosoma carassii infection in the goldfish (Carassius auratus L.). Dev Comp Immunol. (2015) 53:11222. doi: 10.1016/j.dci.2015.06.009

35. Robey FA, Tanaka T, Liu TY. Isolation and characterization of two major serum proteins from the dogfish, Mustelus canis, C-reactive protein and amyloid P component. J Biol Chem. (1983) 258:3889-94.

36. Robey FA, Liu TY. Synthesis and use of new spin labeled derivatives of phosphorylcholine in a comparative study of human, dogfish, and Limulus C-reactive proteins. J Biol Chem. (1983) 258:3895-900.

37. Falco A, Cartwright JR, Wiegertjes GF, Hoole D. Molecular characterization and expression analysis of two new C-reactive protein genes from common carp (Cyprinus carpio). Dev Comp Immunol. (2012) 37:12738. doi: 10.1016/j.dci.2011.10.005

38. Chen R, Qi J, Yao S, Pan X, Gao F, Xia C. Expression, crystallization and preliminary crystallographic analysis of C-reactive protein from zebrafish. Acta Crystallogr Sect F Struct Biol Cryst Commun. (2011) 67:16336. doi: 10.1107/S1744309111037390 
39. Li MF, Chen C, Li J, Sun L. The C-reactive protein of tongue sole Cynoglossus semilaevis is an acute phase protein that interacts with bacterial pathogens and stimulates the antibacterial activity of peripheral blood leukocytes. Fish Shellfish Immunol. (2013) 34:623-31. doi: 10.1016/j.fsi.2012.12.001

40. Takemura A, Nunomura W, Takano K, Hirai H. Novel female protein with biological activities of C-reactive protein and lectin in a viviparous rockfish, Sebastes taczanowskii. J Exp Zool. (1993) 266:188-94.

41. Lin L, Liu TY. Isolation and characterization of C-reactive protein (CRP) cDNA and genomic DNA from Xenopus laevis: a species representing an intermediate stage in CRP evolution. J Biol Chem. (1993) 268:6809-15.

42. Maudsley S, Rowe IF, De Beer FC, Munn EA, Herbert J, Feinstein A, et al. Identification and isolation of two pentraxins from bovine serum. Clin Exp Immunol. (1987) 67:662-73.

43. Morimatsu M, Sakai H, Yoshimatsu K, Minowa O, Yamamoto S, Yatomi K, et al. Isolation and characterization of $\mathrm{C}$-reactive protein and serum amyloid P component from bovine serum. Nippon Juigaku Zasshi. (1989) 51:723-32.

44. Caspi D, Baltz ML, Snel F, Gruys E, Niv D, Batt RM, et al. Isolation and characterization of C-reactive protein from the dog. Immunology. (1984) 53:307-13.

45. Yamamoto S, Tagata K, Nagahata H, Ishikawa Y, Morimatsu M, Naiki M. Isolation of canine $\mathrm{C}$-reactive protein and characterization of its properties. Vet Immunol Immunopathol. (1992) 30:329-39.

46. Funke C, King DP, Brotheridge RM, Adelung D, Stott JL. Harbor seal (Phoca vitulina) C-reactive protein (CRP): purification, characterization of specific monoclonal antibodies and development of an immunoassay to measure serum CRP concentrations. Vet Immunol Immunopathol. (1997) 59:151-62.

47. Maudsley S, Baltz ML, Munn EA, Buttress N, Herbert J, Feinstein A, et al. Isolation and characterisation of goat C-reactive protein. Biochim Biophys Acta. (1987) 924:75-80.

48. Takiguchi M, Fujinaga T, Naiki M, Mizuno S, Otomo K. Isolation, characterization, and quantitative analysis of C-reactive protein from horses. Am J Vet Res. (1990) 51:1215-20.

49. Coe JE, Margossian SS, Slayter HS, Sogn JA. Hamster female protein: a new pentraxin structurally and functionally similar to C-reactive protein and amyloid P component. J Exp Med. (1981) 153:977-91.

50. Coe JE, Ross MJ. Hamster female protein: a divergent acute phase protein in male and female Syrian hamsters. J Exp Med. (1983) 157:1421-33.

51. Tennent GA, Baltz ML, Osborn GD, Butler PJG, Noble GE, Hawkins PN, et al. Studies of the structure and binding properties of hamster female protein. Immunology. (1993) 80:645-51.

52. Kushner I, Somerville JA. Estimation of the molecular size of Creactive protein and Cx-reactive protein in serum. Biochim Biophys Acta. (1970) 207:105-14.

53. Bach BA, Gewurz H, Osmand AP. C-reactive protein in the rabbit: isolation, characterization and binding affinity to phosphocholine. Immunochemistry. (1977) 14:215-9.

54. De Beer FC, Baltz ML, Munn EA, Feinstein A, Taylor J, Bruton C, et al. Isolation and characterization of C-reactive protein and serum amyloid $\mathrm{P}$ component in the rat. Immunology. (1982) 45:55-70.

55. Shrive AK, Cheetham GMT, Holden D, Myles DAA, Turnell WG, Volanakis JE, et al. Three-dimensional structure of human C-reactive protein. Nature Struct Biol. (1996) 3:346-54.

56. Bottazzi B, Doni A, Garlanda C, Mantovani A. An integrated view of humoral innate immunity: pentraxins as a paradigm. Annu Rev Immunol. (2010) 28:157-83. doi: 10.1146/annurev-immunol-030409-101305

57. Liu TY, Syin C, Nguyen NY, Suzuki A, Boykins RA, Lei KJ, et al. Comparison of protein structure and genomic structure of human, rabbit, and Limulus C-reactive proteins: possible implications for function and evolution. J Prot Chem. (1987) 6:263-71.

58. Agrawal A, Bhattacharya S. Binding property of rat and Limulus C-reactive proteins (CRP) to mercury. Experientia. (1989) 45:567-70.

59. Harrington JM, Chou HT, Gutsmann T, Gelhaus C, Stahlberg H, Leippe $\mathrm{M}$, et al. Membrane pore formation by pentraxin proteins from Limulus, the American horseshoe crab. Biochem J. (2008) 413:30513. doi: 10.1042/BJ20071357

60. Agrawal A, Mitra S, Ghosh N, Bhattacharya S. C-reactive protein (CRP) in hemolymph of a mollusc, Achatina fulica Bowdich. Indian J Exp Biol. (1990) 28:788-9.
61. Bose R, Bhattacharya S. C-reactive protein in the hemolymph of Achatina fulica: interrelationship with sex steroids and metallothionein. Comp Biochem Physiol. (2000) 125:485-95. doi: 10.1016/S1095-6433(00)00176-8

62. Mukherjee S, Barman S, Sarkar S, Mandal NC, Bhattacharya S. Anti-bacterial activity of Achatina CRP and its mechanism of action. Indian J Exp Biol. (2014) 52:692-704.

63. Winkelhake JL, Chang RJ. Acute phase (C-reactive) protein-like macromolecules from rainbow trout (Salmo gairdneri). Dev Comp Immunol. (1982) 6:481-9.

64. Winkelhake JL, Vodicnik MJ, Taylor JL. Induction in rainbow trout of an acute phase (C-reactive) protein by chemicals of environmental concern. Comp Biochem Physiol. (1983) 74:55-8.

65. Nakanishi Y, Kodama H, Murai T, Mikami T, Izawa H. Activation of rainbow trout complement by C-reactive protein. Am J Vet Res. (1991) 52:397-401.

66. Liu Y, Iwasaki T, Watarai S, Kodama H. Effect of turpentine oil on C-reactive protein (CRP) production in rainbow trout (Oncorhynchus mykiss). Fish Shellfish Immunol. (2004) 17:203-10. doi: 10.1016/j.fsi.2004.03.003

67. Kodama H, Matsuoka Y, Tanaka Y, Liu Y, Iwasaki T, Watarai S. Changes of C-reactive protein levels in rainbow trout (Oncorhynchus mykiss) sera after exposure to anti-ectoparasitic chemicals used in aquaculture. Fish Shellfish Immunol. (2004) 16:589-97. doi: 10.1016/j.fsi.2003.09.007

68. Mandal C, Sinha S, Mandal C. Lectin like properties and differential sugar binding characteristics of C-reactive proteins purified from sera of normal and pollutant induced Labeo rohita. Glycoconj J. (1999) 16:741-50.

69. Sinha S, Mandal C, Allen AK, Mandal C. Acute phase response of Creactive protein of Labeo rohita to aquatic pollutants is accompanied by the appearance of distinct molecular forms. Arch Biochem Biophys. (2001) 396:139-50. doi: 10.1006/abbi.2001.2592

70. MacCarthy EM, Burns I, Irnazarow I, Polwart A, Greenhough TJ, Shrive AK, et al. Serum CRP-like protein profile in common carp Cyprinus carpio challenged with Aeromonas hydrophila and Escherichia coli lipopolysaccharide. Dev Comp Immunol. (2008) 32:1281-9. doi: 10.1016/j.dci.2008.04.004

71. Pionnier N, Falco A, Miest J, Frost P, Irnazarow I, Shrive A, et al. Dietary $\beta$-glucan stimulate complement and C-reactive protein acute phase responses in common carp (Cyprinus carpio) during an Aeromonas salmonicida infection. Fish Shellfish Immunol. (2013) 34:819-31. doi: 10.1016/j.fsi.2012.12.017

72. Pionnier N, Adamek M, Miest JJ, Harris SJ, Matras M, Rakus KL, et al. $\mathrm{C}$-reactive protein and complement as acute phase reactants in common carp Cyprinus carpio during CyHV-3 infection. Dis Aquat Organ. (2014) 109:187-99. doi: 10.3354/dao02727

73. Samudzi CT, Nguyen NY, Rubin JR. Crystallization and preliminary x-ray diffraction studies of dogfish C-reactive protein. Proteins Struct Funct Genet. (1993) 15:100-2.

74. Bello-Perez M, Falco A, Medina R, Encinar JA, Novoa B, Perez L, et al. Structure and functionalities of the human C-reactive protein compared to the zebrafish multigene family of C-reactive-like proteins. Dev Comp Immunol. (2016) 69:33-40. doi: 10.1016/j.dci.2016.12.001

75. Bello-Perez M, Falco A, Medina-Gali R, Pereiro P, Encinar JA, Novoa $B$, et al. Neutralization of viral infectivity by zebrafish C-reactive protein isoforms. Mol Immunol. (2017) 91:145-55. doi: 10.1016/j.molimm.2017. 09.005

76. Elvitigala DAS, Wan Q, Kim HC, Lee J. Identification of a C-reactive protein like homologue from black rockfish (Sebastes schlegelii) evidencing its potent anti-microbial properties at molecular level. Dev Comp Immunol. (2015) 53:169-78. doi: 10.1016/j.dci.2015.07.007

77. Lee PT, Bird S, Zou J, Martin SAM. Phylogeny and expression analysis of C-reactive protein (CRP) and serum amyloid-P (SAP) like genes reveal two distinct groups in fish. Fish Shellfish Immunol. (2017) 65:4251. doi: 10.1016/j.fsi.2017.03.037

78. Patterson LT, Mora EC. Occurrence of a substance analogous to C-reactive protein in the blood of the domestic fowl. Tex Rep Biol Med. (1964) 22:71621.

79. Marques AT, Nordio L, Lecchi C, Grilli G, Giudice C, Ceciliani F. Widespread extrahepatic expression of acute-phase proteins in healthy chicken (Gallus gallus) tissues. Vet Immunol Immunopathol. (2017) 190:107. doi: 10.1016/j.vetimm.2017.06.006 
80. Sarikaputi M, Morimatsu M, Syuto B, Saito M, Naiki M. A new purification procedure for bovine C-reactive protein and serum amyloid P component. Int J Biochem. (1991) 23:1137-42.

81. Riley RF, Zontine W. Further observations on the properties of dog Creactive protein and the $\mathrm{C}$-reactive protein response in the dog. J Lab Clin Med. (1972) 80:698-703.

82. Ganrot K. Plasma protein response in experimental inflammation in the dog. Res Exp Med. (1973) 161:251-61.

83. Caspi D, Snel FW, Batt RM, Bennett D, Rutteman GR, Hartman EG, et al. C-reactive protein in dogs. Am J Vet Res. (1987) 48:919-21.

84. Fujise H, Takanami H, Yamamoto M, Ohta I, Yamamoto S, Fukase T, et al. Simple isolation of canine C-reactive protein (CRP) by phosphorylcholine (PC) affinity chromatography. J Vet Med Sci. (1992) 54:165-67.

85. Yamamoto S, Abe N, Santsuka H, Shida T, Kishida K, Kuwajima S, et al. Efficient preparation of monospecific anti-canine C-reactive protein serum and purification of canine C-reactive protein by affinity chromatography. Vet Immunol Immunopathol. (1993) 36:293-301.

86. Yamamoto S, Miyaji S, Abe N, Otabe K, Furukawa E, Naiki M. Canine Creactive protein (CRP) does not share common antigenicity with human CRP. Vet Res Commun. (1993) 17:259-66.

87. Jasensky AK, Bondzio A, Murugaiyan J, Siebert U, Roesler U, Kohn B, et al. Characterization of the native C-reactive protein (cCRP) and the corresponding liver mRNA in dogs. Biochem Biophys Res Commun. (2014) 452:462-7. doi: 10.1016/j.bbrc.2014.08.090

88. Vasiu I, Dabrowski R, Martinez-Subiela S, Ceron JJ, Wdowiak A, Pop RA, et al. Milk C-reactive protein in canine mastitis. Vet Immunol Immunopathol. (2017) 186:41-4. doi: 10.1016/j.vetimm.2017.02.005

89. Rubio N, Sharp PM, Rits M, Zahedi K, Whitehead AS. Structure, expression, and evolution of guinea pig serum amyloid $\mathrm{P}$ component and C-reactive protein. J Biochem. (1993) 113:277-84.

90. Yamashita K, Fujinaga T, Okumura M, Takiguchi M, Tsunoda N, Mizuno S. Serum C-reactive protein (CRP) in horses: the effect of aging, sex, delivery and inflammations on its concentration. J Vet Med Sci. (1991) 53:1019-24.

91. Riley RF, Coleman MK. Isolation of C-reactive proteins of man, monkey, rabbit and dog by affinity chromatography on phosphorylated cellulose. Clin Chim Acta. (1970) 30:483-96.

92. Sorensen NS, Tegtmeier C, Andresen LO, Piñeiro M, Toussaint MJM, Campbell FM, et al. The porcine acute phase protein response to acute clinical and subclinical experimental infection with Streptococcus suis. Vet Immunol Immunopathol. (2006) 113:157-68. doi: 10.1016/j.vetimm.2006.04.008

93. Birck MM, Pesonen E, Odermarsky M, Hansen AK, Persson K, Frikke-Schmidt $\mathrm{H}$, et al. Infection-induced coronary dysfunction and systemic inflammation in piglets are dampened in hypercholesterolemic milieu. Am J Physiol Heart Circ Physiol. (2011) 300:H1595-601. doi: 10.1152/ajpheart.01253.2010

94. Dowton SB, Woods DE, Mantzouranis EC, Colten HR. Syrian hamster female protein: analysis of female protein primary structure and gene expression. Science. (1985) 228:1206-8.

95. Dowton SB, Holden SN. C-reactive protein (CRP) of the Syrian hamster. Biochemistry. (1991) 30:9531-8.

96. Dowton SB, Waggoner DJ. Armenian hamster female protein (serum amyloid P component): comparison with the sex-regulated homolog in Syrian hamster. J Immunol. (1989) 143:3776-80.

97. Whitehead AS, Zahedi K, Rits M, Mortensen RF, Lelias JM. Mouse C-reactive protein: generation of cDNA clones, structural analysis, and induction of mRNA during inflammation. Biochem J. (1990) 266:283-90.

98. Bodmer B, Siboo R. Isolation of mouse C-reactive protein from liver and serum. J Immunol. (1977) 118:1086-9.

99. Li Y, Robins JH, Ye J, Huang Z, Wen Q, Zhang G. Adaptive diversity of innate immune receptor family short pentraxins in Murinae. FEBS Lett. (2012) 586:798-803. doi: 10.1016/j.febslet.2012.01.048

100. Patterson LT, Higginbotham RD. Mouse C-reactive protein and endotoxininduced resistance. J Bacteriol. (1965) 90:1520-4.

101. Anderson HC, McCarty M. The occurrence in the rabbit of an acute phase protein analogous to human C reactive protein. J Exp Med. (1951) 93:25-36.

102. Kushner I, Kaplan MH. Studies of acute phase protein. I. An immunohistochemical method for the localization of $\mathrm{Cx}$-reactive protein in rabbits: association with necrosis in local inflammatory lesions. J Exp Med. (1961) 114:961-73.

103. Riley RF, Coleman MK, Hokama Y. Effects of drugs on Cx-protein responses in the rabbit. Arch Int Pharmacodyn Ther. (1964) 148:61-81.

104. Riley RF, Coleman MK, Snow HD. Site of formation of Cx-reactive protein. Experientia. (1969) 25:277-8.

105. Osmand AP, Gewurz H, Friedenson B. Partial amino-acid sequences of human and rabbit C-reactive proteins: homology with immunoglobulins and histocompatibility antigens. Proc Natl Acad Sci USA. (1977) 74:1214-8.

106. Oliveira EB, Gotschlich EC, Liu T-Y. Comparative studies on the binding properties of human and rabbit C-reactive proteins. J Immunol. (1980) 124:1396-402.

107. Wang C-M, Nguyen NY, Yonaha K, Robey F, Liu TY. Primary structure of rabbit C-reactive protein. J Biol Chem. (1982) 257:13610-5.

108. Cabana VG, Gewurz H, Siegel JN. Interaction of very low-density lipoproteins. (VLDL) with rabbit C-reactive protein. J Immunol. (1982) 128:2342-8.

109. Rowe IF, Soutar AK, Trayner IM, Baltz ML, de Beer FC, Walker L, et al. Rabbit and rat C-reactive proteins bind apolipoprotein B-containing lipoproteins. J Exp Med. (1984) 159:604-16.

110. Saxena U, Nagpurkar A, Mookerjea S. Contrasting effect of phosphorylcholine-binding protein from rat and rabbit on heparinlipoprotein interaction: a role of sialic acid. Can J Biochem Cell Biol. (1985) 63:1014-21.

111. Syin C, Gotschlich EC, Liu TY. Rabbit C-reactive protein: biosynthesis and characterization of cDNA clones. J Biol Chem. (1986) 261:5473-9.

112. Hu SI, Miller SM, Samols D. Cloning and characterization of the gene for rabbit C-reactive protein. Biochemistry. (1986) 25:7834-9.

113. Rees RF, Gewurz H, Siegel JN, Coon J, Potempa LA. Expression of a Creactive protein neoantigen (neo-CRP) in inflamed rabbit liver and muscle. Clin Immunol Immunopathol. (1988) 48:95-107.

114. Rénia L, Xia D, Samols D, Nussenzweig V. Transgenic mice expressing C-reactive protein are susceptible to infection with Plasmodium yoelii sporozoites. Infect Immun. (1993) 61:348-9.

115. Lin CS, Xia D, Yun JS, Wagner T, Magnuson T, Mold C, et al. Expression of rabbit C-reactive protein in transgenic mice. Immunol Cell Biol. (1995) 73:521-31.

116. Xia D, Samols D. Transgenic mice expressing rabbit C-reactive protein are resistant to endotoxemia. Proc Natl Acad Sci USA. (1997) 94:2575-80.

117. Black S, Wilson A, Samols D. An intact phosphocholine binding site is necessary for transgenic rabbit C-reactive protein to protect mice against challenge with platelet-activating factor. J Immunol. (2005) 175:1192-6. doi: 10.4049/jimmunol.175.2.1192

118. Jiang S, Xia D, Samols D. Expression of rabbit C-reactive protein in transgenic mice inhibits development of antigen-induced arthritis. Scand J Rheumatol. (2006) 35:351-5. doi: 10.1080/03009740600757963

119. Yu Q, Li Y, Wan Y, Zhao S, Yang P, Chen Y, et al. C-reactive protein levels are associated with the progression of atherosclerotic lesions in rabbits. Histol Histopathol. (2012) 27:529-35. doi: 10.14670/HH-27.529

120. Mattecka S, Bock C, Vogt B, Yapici G, Schrödl W, Janko C, et al. CRP and SAP from different species have different membrane ligand specificities. Autoimmunity. (2013) 46:347-50. doi: 10.3109/08916934.2013.7 80601

121. Schade R, Gotz F, Porstmann B, Friedrich A, Nugel E. The acute phase proteins of the rat, their regulation by hormones and biological significance. Agents Actions Suppl. (1982) 10:213-31.

122. Taylor JA, Bruton CJ, Anderson JK, Mole JE, De Beer FC, Baltz ML, et al. Amino acid sequence homology between rat and human C-reactive protein. Biochem J. (1984) 221:903-6.

123. Bout D, Joseph M, Pontet M, Vorng H, Deslee D, Capron A. Rat resistance to schistosomiasis: platelet-mediated cytotoxicity induced by C-reactive protein. Science. (1986) 231:153-6.

124. Hirai H, Nunomura W, Hatakeyama M. Monoclonal antibodies to human C-reactive protein (CRP) and some characterization of a rat serum protein related to CRP. Protides Biol fluid. (1986) 283-6.

125. Agrawal A, Bhattacharya S. Appearance of C-reactive protein (CRP) in serum and liver cytosol of cadmium-treated rats. Indian J Exp Biol. (1989) 27:1024-7. 
126. Randell E, Mookerjea S, Nagpurkar A. Interaction between rat serum phosphorylcholine binding protein and platelet activating factor. Biochem Biophys Res Comm. (1990) 167:444-9.

127. Rassouli M, Sambasivam H, Azadi P, Dell A, Morris HR, Nagpurkar A, et al. Derivation of the amino acid sequence of rat C-reactive protein from cDNA cloning with additional studies on the nature of its dimeric component. J Biol Chem. (1992) 267:2947-54.

128. Schwalbe RA, Dahlbäck B, Coe JE, Nelsestuen GL. Pentraxin family of proteins interacts specifically with phosphorylcholine and/or phosphorylethanolamine. Biochemistry. (1992) 31:4907-15.

129. Sambasivam H, Rassouli M, Murray RK, Nagpurkar A, Mookeerjea S, Azadi $\mathrm{P}$, et al. Studies on the carbohydrate moiety and on the biosynthesis of rat C-reactive protein. J Biol Chem. (1993) 268:10007-16.

130. Mookerjea S, Francis J, Hunt D, Yang CY, Nagpurkar A. Rat C-reactive protein causes a charge modification of LDL and stimulates its degradation by macrophages. Arterioscler Thromb. (1994) 14:282-7.

131. Mookerjea S, Hunt D. A novel phosphatidylcholine hydrolysing action of C-reactive protein. Biochem Biophys Res Comm. (1995) 208:1046-52.

132. Schwalbe RA, Coe JE, Nelsestuen GL. Association of rat C-reactive protein and other pentraxins with rat lipoproteins containing apolipoproteins $\mathrm{E}$ and A1. Biochemistry. (1995) 34:10432-9.

133. Agrawal A, Bhattacharya S. Possible role of C-reactive protein in detoxication of mercury. Indian J Exp Biol. (1990) 28:638-41.

134. Omtvedt LA, Wien TN, Myran T, Sletten K, Husby G. Serum amyloid $\mathrm{P}$ component in mink, a non-glycosylated protein with affinity for phosphorylethanolamine and phosphorylcholine. Amyloid J Prot Fold Disorders. (2004) 11:101-8. doi: 10.1080/13506120410001728063

135. Bertelsen MF, Kjelgaard-Hansen M, Grøndahl C, Heegaard PM, Jacobsen S. Identification of acute phase proteins and assays applicable in nondomesticated mammals. J Zoo Wildl Med. (2009) 40:199-203. doi: 10.1638/2007-0125.1

136. Isaza R, Wiedner E, Hiser S, Cray C. Reference intervals for acute phase protein and serum protein electrophoresis values in captive Asian elephants (Elephas maximus). J Vet Diagn Invest. (2014) 26:61621. doi: $10.1177 / 1040638714543923$

137. Srere HK, Belke D, Wang LC, Martin SL. Alpha 2-macroglobulin gene expression during hibernation in ground squirrels is independent of acute phase response. Am J Physiol. (1995) 268:R1507-12.

138. Sheldon JD, Johnson SP, Hernandez JA, Cray C, Stacy NI. Acute-phase responses in healthy, malnourished, and otostrongylus-infected juvenile northern elephant seals (Mirounga angustirostris). J Zoo Wildl Med. (2017) 48:767-75. doi: 10.1638/2016-0267.1

139. Ong OTW, Green-Barber JM, Kanuri A, Young LJ, Old JM. Antimicrobial activity of red-tailed phascogale (Phascogale calura) serum. Comp Immunol Microbiol Infect Dis. (2017) 51:41-8. doi: 10.1016/j.cimid.2017.03.001

140. Woo P, Korenberg JR, Whitehead AS. Characterization of genomic and complementary DNA sequence of human C-reactive protein, and comparison with the complementary DNA sequence of serum amyloid $\mathrm{P}$ component. J Biol Chem. (1985) 260:13384-8.

141. Agrawal A, Lee S, Carson M, Narayana SVL, Greenhough TJ, Volanakis JE. Site-directed mutagenesis of the phosphocholine-binding site of human C-reactive protein: role of $\mathrm{Thr}^{76}$ and Trp ${ }^{67}$. J Immunol. (1997) 158, 345-50.

142. Thompson D, Pepys MB, Wood SP. The physiological structure of human C-reactive protein and its complex with phosphocholine. Structure. (1999) 7:169-77.

143. Agrawal A, Simpson MJ, Black S, Carey MP, Samols D. A Creactive protein mutant that does not bind to phosphocholine and pneumococcal C-polysaccharide. J Immunol. (2002) 169:3217-22. doi: 10.4049/jimmunol.169.6.3217

144. Mikolajek H, Kolstoe SE, Pye VE, Mangione P, Pepys MB, Wood SP. Structural basis of ligand specificity in the human pentraxins, C-reactive protein and serum amyloid P component. J Mol Recognit. (2011) 24:3717. doi: 10.1002/jmr.1090.

145. Kaplan MH, Volanakis JE. Interaction of C-reactive protein complexes with the complement system. I. Consumption of human complement associated with the reaction of C-reactive protein with pneumococcal C-polysaccharide and with the choline phosphatides, lecithin and sphingomyelin. J Immunol. (1974) 112:2135-47.
146. Agrawal A, Volanakis JE. Probing the C1q-binding site on human C-reactive protein by site-directed mutagenesis. J Immunol. (1994) 152:5404-10.

147. Agrawal A, Shrive AK, Greenhough TJ, Volanakis JE. Topology and structure of the Clq-binding site on C-reactive protein. J Immunol. (2001) 166:39984004. doi: 10.4049/jimmunol.166.6.3998

148. Hammond DJ Jr., Singh SK, Thompson JA, Beeler BW, Rusinol AE, Pangburn $\mathrm{MK}$, et al. Identification of acidic $\mathrm{pH}$-dependent ligands of pentameric C-reactive protein. J Biol Chem. (2010) 285:3623544. doi: 10.1074/jbc.M110.142026.

149. Singh SK, Thirumalai A, Pathak A, Ngwa DN, Agrawal A. Functional transformation of C-reactive protein by hydrogen peroxide. J Biol Chem. (2017) 292:3129-36. doi: 10.1074/jbc.M116.773176

150. Singh SK, Thirumalai A, Hammond DJ Jr., Pangburn MK, Mishra VK, Johnson DA, et al. Exposing a hidden functional site of C-reactive protein by site-directed mutagenesis. J Biol Chem. (2012) 287:35508. doi: 10.1074/jbc.M111.310011

151. Agrawal A, Gang TB, Rusiñol AE. Recognition functions of pentameric C-reactive protein in cardiovascular disease. Mediators Inflamm. (2014) 2014:1-6. doi: 10.1155/2014/319215

152. Li H-Y, Wang J, Meng F, Jia ZK, Su Y, Bai Q-F, et al. An intrinsically disordered motif mediates diverse actions of monomeric C-reactive protein. J Biol Chem. (2016) 291:8795-804. doi: 10.1074/jbc.M115.6 95023

153. Yother J, Volanakis JE, Briles DE. Human C-reactive protein is protective against fatal Streptococcus pneumoniae infection in mice. J Immunol. (1982) 128:2374-6.

154. Szalai AJ, Briles DE, Volanakis JE. Human C-reactive protein is protective against fatal Streptococcus pneumoniae infection in transgenic mice. $J$ Immunol. (1995) 155:2557-63.

155. Suresh MV, Singh SK, Ferguson DA Jr., Agrawal A. Role of the property of C-reactive protein to activate the classical pathway of complement in protecting mice from Streptococcus pneumoniae infection. J Immunol. (2006) 176:4369-74. doi: 10.4049/jimmunol.176.7.4369

156. Suresh MV, Singh SK, Ferguson DA Jr., Agrawal A. Human Creactive protein protects mice from Streptococcus pneumoniae infection without binding to pneumococcal C-polysaccharide. J Immunol. (2007) 178:1158-63. doi: 10.4049/jimmunol.178.2.1158

157. Agrawal A, Suresh MV, Singh SK, Ferguson DA Jr. The protective function of human C-reactive protein in mouse models of Streptococcus pneumoniae infection. Endocr Metab Immune Disord Drug Targets. (2008) 8:2317. doi: $10.2174 / 187153008786848321$

158. Gang TB, Hammond DJ Jr., Singh SK, Ferguson DA Jr., Mishra VK, Agrawal A. The phosphocholine-binding pocket on C-reactive protein is necessary for initial protection of mice against pneumococcal infection. J Biol Chem. (2012) 287:43116-25. doi: 10.1074/jbc.M112.4 27310

159. Simons JP, Loeffler JM, Al-Shawi R, Ellmerich S, Hutchinson WL, Tennent GA, et al. C-reactive protein is essential for innate resistance to pneumococcal infection. Immunology. (2014) 142:414-20. doi: 10.1111/imm.12266.

160. Gang TB, Hanley GA, Agrawal A. C-reactive protein protects mice against Streptococcus pneumoniae infection via both phosphocholine-dependent and phosphocholine-independent mechanisms. Infect Immun. (2015) 83:184552. doi: 10.1128/IAI.03058-14

161. Bhakdi S, Torzewski M, Klouche M, Hemmes M. Complement and atherogenesis. Binding of CRP to degraded, nonoxidized LDL enhances complement activation. Arterioscler Thromb Vasc Biol. (1999) 19:2 348-54.

162. Singh SK, Suresh MV, Prayther DC, Moorman JP, Rusinol AE, Agrawal A. Creactive protein-bound enzymatically modified low-density lipoprotein does not transform macrophages into foam cells. J Immunol. (2008) 180:431622. doi: 10.1016/j.jvs.2009.07.006

163. Agrawal A, Hammond DJ Jr., and Singh SK. Atherosclerosis-related functions of C-reactive protein. Cardiovasc Haematol Disorders Drug Targets. (2010) 10:235-40. doi: 10.1161/01.ATV.0000079512.66448.1D

164. Singh SK, Suresh MV, Voleti B, Agrawal A. The connection between C-reactive protein and atherosclerosis. Ann Med. (2008) 40:110-20. doi: 10.1080/07853890701749225 
165. Teupser D, Weber O, Rao TN, Sass K, Thiery J, Fehling HJ. No reduction of atherosclerosis in C-reactive protein (CRP)-deficient mice. J Biol Chem. (2011) 286:6272-9. doi: 10.1074/jbc.M110.161414

166. Kovacs A, Tornvall P, Nilsson R, Tegnér J, Hamsten A, Björkegren J. Human C-reactive protein slows atherosclerosis development in a mouse model with human-like hypercholesterolemia. Proc Natl Acad Sci USA. (2007) 104:13768-73. doi: 10.1073/pnas.0706027104

167. Braig D, Nero TL, Koch HG, Kaiser B, Wang X, Thiele JR, et al. Transitional changes in the CRP structure lead to the exposure of proinflammatory binding sites. Nature Commun. (2017) 8:14188. doi: 10.1038/ncomms14188

168. Ansar W, Mukhopadhyay S, Habib SK, Basu S, Saha B, Sen AK, et al. Disease-associated glycosylated molecular variants of human Creactive protein activate complement-mediated hemolysis of erythrocytes in tuberculosis and Indian visceral leishmaniasis. Glycoconj J. (2009) 26:115169. doi: 10.1007/s10719-009-9236-y

169. Das T, Sen A, Kempf T, Pramanik SR, Mandal C, Mandal C. Induction of glycosylation in human C-reactive protein under different pathological conditions. Biochem J. (2003) 373:345-55. doi: 10.1042/BJ200 21701
170. Das T, Mandal C, Mandal C. Variations in binding characteristics of glycosylated human C-reactive proteins in different pathological conditions. Glycoconj J. (2004) 20:537-43. doi: 10.1023/B:GLYC.0000043290.9 0182.e6

171. Pathak A, Singh SK, Thirumalai A, Armstrong PB, Agrawal A. Evolution of a host-defense function of C-reactive protein from horseshoe crab to humans. J Immunol. (2016) 196(Suppl. 1):132.5.

Conflict of Interest Statement: The authors declare that the research was conducted in the absence of any commercial or financial relationships that could be construed as a potential conflict of interest.

Copyright (๑) 2019 Pathak and Agrawal. This is an open-access article distributed under the terms of the Creative Commons Attribution License (CC BY). The use, distribution or reproduction in other forums is permitted, provided the original author(s) and the copyright owner(s) are credited and that the original publication in this journal is cited, in accordance with accepted academic practice. No use, distribution or reproduction is permitted which does not comply with these terms. 